\title{
Teaching Young Children Early Mathematics through Music and Movement
}

\author{
Kamariah Abu Bakar \\ Faculty of Education, Universiti Kebangsaan Malaysia \\ [National University of Malaysia], Selangor, Malaysia \\ https://orcid.org/0000-0001-8134-6182
}

\author{
Mohamad Azam Samsudin \\ Department of Early Childhood Studies, Faculty of Creative Industries, \\ Universiti Tunku Abdul Rahman [Tunku Abdul Rahman University], Selangor, Malaysia \\ https:// orcid.org/0000-0002-1304-6222
}

\begin{abstract}
The purpose of this study was to explore the integration of music and movement elements into young children's mathematics classrooms. Using a qualitative approach, this research was a case study. Three teachers were purposely selected as participants for this study. The teachers were interviewed to gain information about the songs and movements they chose to employ into their instruction. Additionally, their lessons were observed to attain the ways they incorporated music and movement. These sessions were video recorded to gain a rich picture of the songs and movements incorporated as well as the benefits of such practice in the teaching and learning of mathematics. The findings from the interviews (with teachers), classroom observations, and photographs exhibited that the teachers used familiar, easy and simple songs to be incorporated in their instruction. It was also evident that embedding music and movement activities into young children's mathematics lessons had a positive impact on the students' learning of early mathematics. The students focused on what the teachers were doing and repeating after them. This enhanced their mathematics learning. The implication of this study is that mathematics instruction should be employed in a fun yet meaningful way by incorporating music and movement activities as teaching and learning activities. More importantly, is that children learn mathematics with understanding.
\end{abstract}

Keywords: teaching and learning; young children; numbers; mathematics; music; movement

\section{Introduction}

The Malaysian Education Development Plan (2013-2025) outlines several educational programs that serve an important function in supporting children's development starting from preschool level to primary education (Malaysia Education Blueprint, 2013). With regard to young children's education, the National Standard Preschool Curriculum (NSPC) listed various approaches, strategies, and techniques to be implemented into instruction including inquirybased learning, project-based learning, mastery approaches and learning through 
play (KSPK, 2017) to help children develop physically, emotionally and cognitively. Music and movement are considered as one of the learning techniques frequently used by teachers of young children. To develop children holistically, instruction based on the diversity of intelligence (Gardner, 1993) is often employed in preschool settings due to its potential in facilitating the children's development in various domains.

Previous research emphasized mathematics concepts as amongst the most challenging subject. Students often find it troublesome to understand abstract mathematics concepts (Azlina, 2003). Additionally, researchers found that the traditional method of instruction practiced by teachers was ineffective, because it is not capable of reaching students with different needs and learning styles (Scott, 2005). In order to tackle such problems, teachers introduced various techniques to assist children in learning mathematics using meaningful ways that involve the play approach and using multiple representations (Bakar et al. (2020); Rosli et al., 2015; Abdullah et al., 2014).

The National Council of Teachers Mathematics (NCTM) in the USA and NSPC in Malaysia suggested that educators employ effective teaching approaches including incorporating other content areas such as music and movement to help children acquire skills and knowledge in a meaningful way (Kementerian Pendidikan Malaysia [Ministry of Education], 2017; NCTM, 2000). However, studies embracing music and movement activities in mathematics are limited. Moreover, earlier studies have focused more on the incorporation of music and movement into the learning of language and literacy (Wiggins, 2007; Riddle, 2016). In contrast, there is a need for more studies to be done on the integration of music and movement into mathematics learning, creating a gap deserving of further investigation into music as a context for classroom educational activities that help explore and experience mathematics concepts. The Board of Studies, New South Wales (BOSNSW) defined integration as "purposeful planning by teachers, of strategies and learning experiences to enhance learning across key learning areas" (Board of Studies NSW, 1996). Hence, this study intended to investigate musical activities in a broader educational context by incorporating music and movement into mathematics lessons to ascertain whether this approach impacted mathematics learning in a positive way similar to the way music and movement benefited children's reading, writing and speaking skills.

\section{Research Background}

In many young children's educational settings worldwide, music and movement are part of the daily routine that brings enjoyment to young children. Besides functioning as an enjoyable routine for children, music and movement are increasingly integrated into teaching and learning sessions. In the Malaysian context, the National Standard Preschool Curriculum (NSPC) is aimed to equip preschool children with critical skills including reading, speaking, writing, counting, and thinking as preparation to enter Year One in primary school (Kementerian Pendidikan Malaysia [Ministry of Education], 2017). While teachers have been practicing interdisciplinary instruction for many years that incorporates subjects including Science and Technology, Communication Skills, Physical and Aesthetic Development, Spirituality, Attitude and Values, and Humanity and Personal Skills (as recommended by the NSPC), the integration of music and movement into mathematics teaching and learning should be emphasized. This is to ensure that students learn these critical skills in an integrated means. Most importantly is that they possess all the important knowledge and skills in a fun yet meaningful way. 
The integration of music and movement into mathematics learning enables students to achieve both mathematics as well as arts and creativity objectives as stated in the learning standards worldwide and the Malaysian curriculum for young children. For example, the National Council of Teachers of Mathematics USA (NCTM, 2000) and the NSPC - Malaysia (Kementerian Pendidikan Malaysia [Ministry of Education], 2017) demand students to connect mathematics with other areas or subjects. Additionally, the National Association for the Education of Young Children (NAEYC) (NAEYC, 2009) highlights the importance of integrating mathematics with songs, explore the relationships between them, have rich opportunities to express aesthetic aspects through music, and have children experience self-problem solving. Integrating music and movement helps enhance learning by providing a pressure-free environment as well as stimulates exploration and fun learning that permit children to have an active engagement in learning (Johnson \& Edelson, 2003). Music and movement are recognized as the most common method used by teachers during teaching and learning sessions. Music is considered as amongst the greatest source of education (Elizabeth, 2016) as it creates a positive environment that supports self-control and self-efficacy. Music, art and creativity should not be separated from young children's life and learning as these activities provide them with a fun yet meaningful experience (Lagerlöf et al., 2013).

Researchers worldwide have investigated and hence recognized the potential of music and movements themed activities in enhancing student's creativity, social skills, well-being, and health (Garaigordobil \& Berrueco, 2011; Lobo \& Winsler, 2006; Quin et al., 2007). The integration of music and movement activities into teaching and learning helped facilitate various aspects of learning that contributed to the holistic development of children. The integration of music into mathematics teaching and learning should be encouraged, as such practice requires musical training and equipment that are inexpensive (Capraro \& Tillman, 2013). Mathematics teachers have found the potential of music activities to teach different mathematics topics and concepts such as number concepts, basic operations and geometry (An \& Tillman, 2015). Also, students were reported to engage in higher levels of thinking and participated more actively in mathematics explorations and sense-making activities (An et al., 2013); (An \& Tillman, 2015); (Robertson \& Lesser, 2013).

\section{The Framework}

This study is based on a theoretical framework that includes the Multiple Intelligences theory to determine the effect of incorporating music and movement into young children's mathematics learning. Howard Gardner's theory of Multiple Intelligences (MI) highlights students' different abilities to learn and incorporates a combination of two or more intelligences to enhance learning (Gardner, 1993). As students understand and learn skills and knowledge from various means, Gardner proposed that teachers employ instructions in various ways to provide students with opportunities for understanding and building concepts in each of the intelligences. For example, by incorporating music activities into mathematics lessons, students' mathematical understanding could be enhanced. Especially for students who grapple to understand mathematics concepts, Gardner (1993) suggested that they should be provided with an alternative means to help build conceptual understanding (Kassell, 1998). Additionally, embedding music and mathematics provide children with a fun means for building logical intelligence alongside with their musical intelligence (Shilling, 2002). More importantly, learning mathematics through engagement in music activities could help them comprehend mathematics more easily (Johnson \& Edelson, 2003). 
The theory of multiple intelligences, with its unique interpretation of intelligence and great integration, provides a theoretical basis for the professional development of mathematics teachers. For the present study, Gardner's theory provided a framework that helps to study the use of arts-mathematics integration as a means to provide a rich and stimulating mathematics learning environment. It opens up a new horizon especially in renewing teachers' traditional educational ideas and enriching their teaching practice. The theory of multiple intelligences can prompt teachers to rethink the current problems of mathematics education and teaching from a new perspective and provide new ideas to improve teaching and evaluation views.

This study is aimed at exploring the integration of music and movement in the educational setting of preschool children. Specifically, this study intended to answer the following research questions:

1. What are the music and movement elements used in early mathematics instruction?

2. How do music and movement benefit the teaching and learning of early mathematics in preschool classrooms?

\section{Research Design}

This study used a qualitative approach because of its appropriateness in exploring the integration of music in mathematics learning. Qualitative research is "an inquiry process of understanding based on distinct methodological traditions on inquiry that explore a social or human problem. The researcher builds a complex, holistic picture, analyses words, reports details of informants, and conducts the study in a natural setting" (Creswell, 1998, p.15).

In the present study, a case study research design was used to obtain in-depth information about the integration of music and movement in mathematics learning, which is critical to understanding the ongoing phenomenon in a real-life context by using various data collection techniques to collect evidence (Yin, 2009) such as interview and observation. A case study can be identified as an intensive report of a unique case that explains the special phenomena, events or incidents, and personal identities and activities (Yin, 2009).

\section{Research Method}

\subsection{Participants}

The participants included three preschool teachers and thirty students. The criteria for selecting the teachers included i) certified preschool teachers with at least four years teaching experience, ii) employing music and movement activities in mathematics instruction, and iii) voluntary participation in the study. As for the students, only those who provided approval for their participation were included in the study. The participants were labelled as Teacher 1 (T1) , Teacher 2 (T2), and Teacher 3 (T3) to protect their privacy and confidentiality.

\subsection{Data Collection}

This article focused only on the number concepts (numbers below 20) although other mathematics concepts were also taught by the teachers. Data collection included observations, interviews, field notes, and video recordings. Various data sources were collected to serve various purposes. Observations of the mathematics lessons in a classroom setting were done to obtain information pertaining to the teaching and learning situations and events, interactions between teacher-children and children-children as well as the children's behaviours during their engagement in the mathematics-music activities. 
Observing how the teachers employed music and movement activities in mathematics lessons and the children's behaviours as a result of integrating music in mathematics were important data that explained the benefits of such integration into mathematics learning.

Interviews with the teachers were employed i) prior to the study, and ii) after the teaching sessions. These interviews aimed at achieving details about the teachers' experiences and thoughts related to mathematics instruction that embedded music and movements. A range of data sources obtained for the study allowed the researcher to obtain a rich picture (Ghazali \& Sufean, 2016) about children's understanding of mathematics concepts as a result of embedding mathematics lessons with music and movement.

\subsection{Ethics}

Each teacher was observed at least three times and all teaching sessions were video recorded. Prior to recording the lessons, the researcher obtained permission from the teachers and the children. All participants confirmed that their participation was voluntary and provided permission to being video-recorded.

\subsection{Data Analysis}

Firstly, all interviews were transcribed. Then, the researcher proceeded with the video analysis of teaching and learning sessions that integrated music and movement in mathematics classrooms. The researcher went through six phases in conducting thematic analysis as listed by Medina (2002): i) becoming familiar with the data; ii) generating initial codes; iii) searching for themes; iv) reviewing themes; v) Defining and naming themes; and vi) producing the report. The combination of all data provided evidence for the children's mathematics learning. These data afforded rich information about the ways teachers employed music and movements in mathematics as well as the benefits such activities had on children's mathematics learning.

\section{Findings}

The ways that the teachers integrated music and movement activities in classrooms when teaching mathematics were explored. Additionally, the advantages of integrating music and movements into mathematics instruction were investigated.

\subsection{What are the music and movement elements used in early mathematics instruction?}

The first teacher (T1) stated that when selecting music or songs to be integrated into mathematics lessons, he often used songs that contain mathematics (such as numbers) that are familiar to the children. "....easy to use familiar songs....in which children are familiar with them...". He further explained that this is important to enable the children to easily sing them compared to having them learn a new song that requires a lot of time. In cases where there are no suitable songs that can be linked directly to the mathematics topic or concept he was to teach, he altered the lyrics to ensure it contained the concepts that the children were going to learn. He further added that by doing so aided children to learn mathematics more quickly and easily than using traditional means (i.e., chalk and talk by the teacher). The songs used in this study included "Pukul berapa datuk harimau" [What is the time now Mr. Tiger], and "Satu jari tap tap tap" [One finger tap, tap, tap]. The song 'What is the time now Mr. Tiger' is a popular game song played by Malaysian children that required the children to chase their friends when it comes to a particular time. In this study, this song was incorporated during the topic of time and clock. On the other hand, the song 'One finger tap, 
tap, tap' was used to teach the concept of numbers and quantities. The children were observed to enjoy the short, easy, and repetitive songs that in turn facilitated and strengthened mathematics learning by singing the lyrics and tapping their fingers to count.

T3 agreed that songs familiar to the children were his priority when selecting suitable songs to be integrated into his instruction. He further stressed that he selected familiar melodies for his lessons. Additionally, both teachers agreed that familiar rhythms were among the important elements when selecting music or songs to be embedded in mathematics lessons for young children.

When asked further about the music or song used by the teachers, T1 stated that "... firstly, teachers must ensure that the songs contain simple lyrics and words, that children understand...". Other teacher participants including T1, T2, and T3 supported the statement made by $\mathrm{T} 1$ by adding other important criteria in selecting music or songs for their preschool children including repetitive words, lyrics that are not too long, easy to memorize, and understandable to the children.

In terms of movements, $\mathrm{T} 1$ stated that he chose simple and easy movements to enable children to follow what the teacher had demonstrated. He mentioned that "...the songs contain simple and easy movement ..... so that children can follow the movements....". Like the first teacher, both T3 and T4 too integrated songs that contain easy movement. T3 added that this is to enable children to memorize the steps or movements that they were to exhibit while singing the song. Apparently, the teachers integrated songs and rhymes that are familiar to the children. As for movement, they ensured simple movements were integrated into classroom learning. Using familiar songs with simple, short, and easy lyrics as well as movements is beneficial in supporting mathematical learning. For instance, the songs and movements used in this study supported children's numeral recognition and number formation.

\subsection{How do music and movement benefit the teaching and learning of early mathematics in preschool classrooms?}

T2 stated how music and movement impacted children's behaviour. "... music and movement can attract children's attention.... they can pay attention to us when they sing songs and make movement.......". When music and movement are integrated into her lessons, she found that children focused their attention on the teacher.

A scene photographed during the teaching session proved the statement made by T2. As can be seen in Figure 1, the whole class fully paid attention to the teacher standing in front of the classroom.

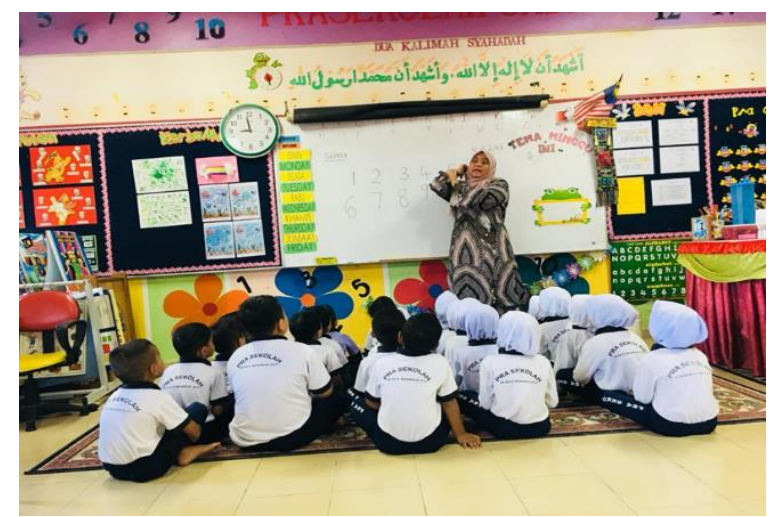

Figure 1: The children focused their attention on the teacher 
The teacher taught the children about numbers. She demonstrated how the numbers look like using her body. For example, she gestured with her hand and arm how numeral seven looks like. As shown in Figure 1, all children in the classroom focused their attention and showed interest in what the teacher was demonstrating (gesturing with her hand the numeral seven) and saying (i.e., singing). None of the children were observed chatting or talking with others. The children did not show signs of being distracted by other things happening surrounding the classroom and were focused on the lesson. When music and movement were integrated into the teaching and learning session, children's attention was focused fully on the teacher. This enabled the teacher to deliver the lesson easily. Integration of songs in mathematics assisted children to focus their attention and participate in the music and movement activities for a longer time. The act of singing and making movements seemed particularly helpful to capture the children's attention and draw out mathematical responses including tapping their fingers, and pointing to objects in the classroom while counting and singing the number song. GP3 further described that the integration of music and movement activities empowered children to participate actively in the mathematics tasks. As evident in Figure 2, all children engaged enthusiastically in the session. Not a single child refused to get involved in the activities and all the children participated in the activity.

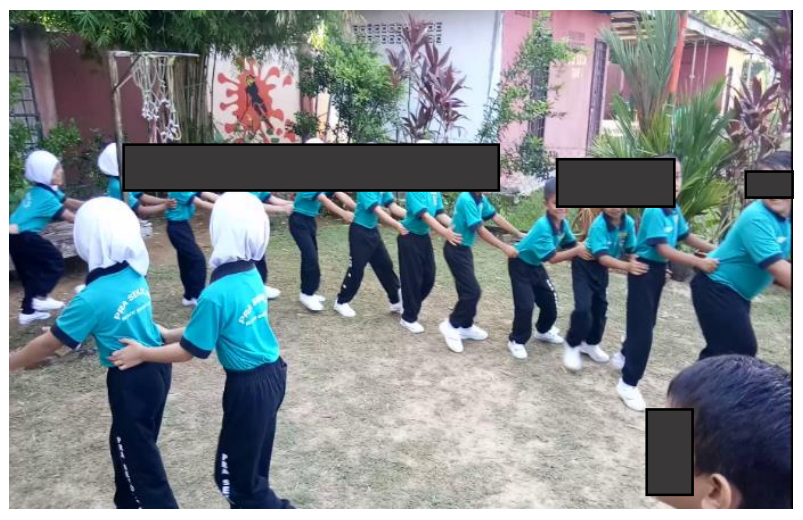

Figure 2. Making movement (forming a circle) whilst singing

The teacher requested the children to form a circle and simultaneously sing. As can be seen in Figure 2, all children participated and formed a chain by holding their friend's body and made a circle (when learning about shapes; in this case, to form a circle with their body). Clearly, the integration of songs and movements in mathematics helped children focus and engaged their attention in the music and movement activities for a longer time. The act of singing and making movements appeared particularly useful in capturing the children's attention and draw out mathematical responses including tapping their fingers, pointing to objects in the classroom, forming shapes with the body while counting, forming shapes and singing. Learning mathematics through music and movement provided the children with enjoyable moments in a pressure-free environment that helped create a positive mathematics learning environment. This in turn helped the children feel comfortable and hence ease the process of knowledge transfer.

The use of music and movements helped enhance the children's learning of mathematics concepts as well as understanding. While singing the song "One finger, tap, tap, tap", the children were also counting their fingers at the same time. The act of saying aloud the number names (i.e., through singing) and counting or pointing to objects or fingers helped the children to match the number 
names to the quantity. The children's engagement in the mathematics songs and movements helped the reinforcement of mathematics learning in various ways. Obviously, mathematics-infused songs (e.g., Number songs) helped reinforce readily mastered concepts (i.e., number names) that the children had practiced in previous lessons. Singing the number songs aloud helped the children familiarize themselves with the correct order of the number names. While singing aloud the song and making movements, the children were simultaneously counting and holding up their fingers to represent the quantity. The teacher (T2) stated that the children successfully answered the questions related to the mathematics lesson. T2 affirmed that "... the kids are able to learn quickly, when we ask questions, these kids will be able to answer and understand the concepts taught in the classroom ...". When learning number names, it is particularly important that young children are able to say the number names in the correct sequence. Using number songs such as "One finger tap, tap, tap" and making relevant movements (tapping their fingers) helped the children memorize the sequence of the number names easily and correctly as they rehearse the song.

\section{Discussion of Findings}

The discussion of the findings presented in this article is organized into three main themes: (i) familiar, easy and simple songs; (ii) increase children's attention; and (iii) enhance children's learning and understanding.

\subsection{Familiar, easy, and simple songs}

Music and movement are useful memory aids. As evident in the number of songs, music plays a critical role in engaging children in mathematical activities and learning while developing mathematical recall. Previous studies have highlighted the link between music and memory recall. Songs help to store and release information when needed, hence they functioned as a valuable means for mathematics teaching and learning (Medina, 2002; Mora, 2000). As highlighted by Lake (2002) and Samson and Zatorre (2004), songs that comprise of catchy and repetitive words or lyrics ease children in memorizing them. In mathematics learning, it is vital that children have a strong memory to enable them to perform in mathematics (Conners, Rosenquist \& Taylor, 2001). Constant practice over time is the key to retention, and rehearsal or practice can help to consolidate new learning into long-term memory (Hunter, 2004). Hence, it is beneficial that children regularly recite, practice and rehearse music-mathematics songs to aid in automaticity (Laws, MacDonald \& Buckley, 1996). Through singing, children can make meaningful associations and rehearse or practice mathematical concepts, increasing the chance for new learning to be fastened and strengthened.

\subsection{Increase Children's Attention}

Interest is a powerful strength that stimulates children to focus on individuals, objects, events, and activities. Apparently, songs integrated into learning sessions can indeed attract the children to focus on the teacher's words and actions; hence, capturing their interest. When children's attention are focused on the teacher, it is easier for the teacher to deliver the lesson. Therefore, making it easy for the teacher to transfer the skills and knowledge to the children. As asserted by An and Tillman (2015), children who have better concentration are more cognitively engaged in mathematics learning.

\subsection{Enhance Children's Learning and Understanding}

Among all the mathematics topics, basic knowledge and skills related to the topic of numbers play a critical function when processing mathematics. It is necessary that teachers help children master this basic knowledge because basic number knowledge and skills are key to more complex mathematics topics (Scott, 2005). 
For example, children should master counting skills to enable them to solve problems involving addition and subtraction problems. When children lack counting skills, it is difficult for them to proceed with the addition process.

Clearly, this study provided evidence for the benefits of integrating music into mathematics learning; by proving music as a potential means to assist children in mastering basic number skills. Rhyme and rhythm (in the song) and repetition in counting helped reinforce learning (Geist, Geist, \& Kuznik, 2012). Repetitively reciting the number names helped ease the students to memorize the number order or sequence. Furthermore, when children learn mathematics in a fun way, it helped the retention of information and knowledge.

\section{Conclusion}

This study presented the benefits of using music and movement to teach early mathematics in preschool classrooms. Evidently, music activities embedded in mathematics instruction enhanced learning in many ways such as attracting children's attention towards the teachers, providing a stress-free environment which empowers the learning of mathematics.

The findings of the present study clearly exhibited the potential of music and movement activities in enhancing mathematics learning. Embedding music and movement activities clearly invites the active participation and engagement of children in mathematical ways (e.g., through counting aloud while singing). Hence, it is imperative that teachers switch from traditional learning that often resulted in passive participation and is focused on one domain to active integrated learning by engaging children in various music and movement activities whilst learning mathematics concepts.

This study has an implication for teacher preparation and training. Teachers should be provided with knowledge, skills, and experiences pertaining to blended learning. Educators should no longer be dependent only on traditional approaches, but to diversify their teaching approaches towards preparing children for the $21^{\text {st }}$ century life and future learning. Additionally, it is imperative that effective instruction especially pertaining to the use of music and movement be embedded in all learning areas and subjects particularly among teachers of young children. Also, it is expected that mathematics learning will be enjoyable yet meaningful by means of incorporating a wide range of music activities into mathematics classrooms. Further research examining the link between music and mathematics learning should be done as such research could contribute to effective mathematics instruction.

\section{Acknowledgment}

This research was supported by grants provided by the Universiti Kebangsaan Malaysia [The National University of Malaysia] (GGPM-2019-011) and (GG-2019061).

\section{References}

Abdullah, N., Halim, L., \& Zakaria, E. (2014). Vstops: A Thinking Strategy and Visual Representation Approach in Mathematics Word Problem Solving toward Enhanching STEM Literacy. Eurasia Journal of Mathematics, Science E Technology Education, 10(3), 165-174. https://doi.org/10.12973/eurasia.2014.1073a

An, S. A., \& Tillman, D. A. (2015). Music Activities as a Meaningful Context for Teaching Elementary Students Mathematics: A Quasi-Experiment Time Series Design with Random Assigned Control Group. European Journal of Science and Mathematics Education, 3(1), 45-60. https://10.30935/scimath/9420 
An, S.A, Capraro, M. M., \&, Tillman, D. (2013). Elementary teachers integrate music activities into regular mathematics lessons: effects on students' mathematical abilities. Journal for Learning through the Arts, 9(1), 1-20. https://doi.org/10.21977/D99112867

Azlina, A. (2003). Keyakinan Guru-guru Program Pensiswazahan Kursus Perguruan Lepasan Diploma, Mengajar Sains Tulen Dan Matematik Tambahan Dalam Bahasa Inggeris [Confidence of Teachers of the Graduate Program of PostDiploma Teaching Courses, Teaching Pure Science and Additional Mathematics in English]. Tesis Sarjana Muda. Universiti Teknologi Malaysia: http://merr.utm.my/id/eprint/7521

Bakar, K. A., Mohamed, S., Yunus, F., \& Karim, A.A. (2020). Use of Multiple Representations in Understanding Addition: The Case of Pre-School Children. International Journal of Learning, Teaching and Educational Research, 19(2), 292-304. https://doi.org/10.26803/ijlter.19.2.18

Board of Studies NSW. (1996). Curriculum integration. http://www.bosnswk6.nsw.edu.au

Conners, F. A., Rosenquist, C. J., \& Taylor, L. A. (2001). Memory training for children with Down syndrome. Down Syndrome Research and Practice, 7(1), 2533. https://doi.org/10.3104/reports.111

Creswell, J. W. (1998). Qualitative research and design: Choosing among five traditions (pp. 46). Thousands Oaks, CA: Sage. https:// doi.org/10.4148/2470-6353.1252

Edelson, R. J., \& Johnson, G. (2003). Music makes math meaningful. Childhood Education, 80(2), 65-70. https://doi.org/10.1080/00094056.2004.10521259

Elizabeth, A. O. (2016). The interrelation between music education and cultural education in early childhood music education in Kenya. International Yearbook for Research in Arts Education.

Garaigordobil, M., \& Berrueco, L. (2011). Effects of a play program on creative thinking of preschool children. The Spanish Journal of Psychology, 14(2), 608-618. https://doi.org/10.5209/rev_SJOP.2011.v14.n2.9

Gardner, H. (1993). Multiple intelligences: The theory into practice. New York: Basic Books.

Geist, K., Geist, E. A., \& Kuznik, K. (2012). The patterns of music: Young children learning mathematics through beat, rhythm, and melody. Young Children, 67(1), 74-79. https://www.jstor.org/stable/42731136

Ghazali, D., \& Sufean, H. (2016). Metodologi Penyelidikan Dalam Pendidikan (2nd ed.). Penerbit UM.

Hunter, M. (2004). Mastery teaching: Increasing instructional effectiveness in elementary and secondary schools. Thousand Oaks, CA: Corwin Press.

Johnson, G., \& Edelson, R. J. (2003). The integration of mathematics and music in the primary school classroom. Teaching Children Mathematics, 4, 475-479. https:// doi.org/10.2307/2295499

Kassell, C. (1998). Music and the theory of multiple intelligences: Gardner's theory has lent itself to classroom activities that exercise different intelligences, but some music activities supposedly based on this theory may be misguided. Music Educators Journal, 84(5), 29-32. https://doi.org/10.2307\%2F3399127

Kementerian Pendidikan Malaysia. (2017). Kurikulum Standard Prasekolah Kebangsaan. Kuala Lumpur: Bahagian Perkembangan Kurikulum.

Lagerlöf, P., Wallerstedt, C., \& Pramling, N. (2013). Engaging children's participation in and around a new music technology through playful framing. International Journal of Early Years Education, 21(4), 325-335. https://doi.org/10.1080/09669760.2013.867170 
Lake, R. (2002). Enhancing acquisition through music. The Journal of the Imagination in Language Learning and Teaching 7, 98-106. http://works.bepress.com/robertlake/1/

Laws, G., MacDonald, J., \& Buckley, S. (1996). The effects of a short training in the use of a rehearsal strategy on memory for words and pictures in children with Down syndrome. Down Syndrome Research and Practice, 4(2), 70-78. https://doi.org/10.3104/reports.65

Lobo, Y.B., \& Winsler, A. (2006). The effects of a creative dance and movement program on the social competence of head start preschoolers. Social Development, 15, 501519. https://doi.org/10.1111/j.1467-9507.2006.00353.x

Malaysia Education Blueprint. (2013). Laporan Awal. Pelan Pembangunan Pendidikan Malaysia $2013 \quad-\quad 2025 . \quad$ Education, 27(1), 1-268. https://doi.org/10.1016/j.tate.2010.08.0

Medina, S. L. (2002). Using music to enhance second language acquisition: From theory to practice. In J. Lalas, \& S. Lee (Eds.), Language, literacy and academic development for English language learners. http://www.forefrontpublishers.com/eslmusic/articles/06

Mora, C. F. (2000). Foreign language acquisition and melody singing, ELT Journal 54(2), 146-152. https://doi.org/10.1093/elt/54.2.146

National Association for the Education of Young Children. (2009). Developmentally appropriate practice in early childhood programs serving children from birth through age 8. http://www.naeyc.org/files/naeyc/file/positions/PSDAP.pdf

NCTM. (2000). National Council of Teachers of Mathematics, Principles and Standards for school mathematics. Reston, VA: National Council of Teachers of Mathematics.

Quin, E., Redding, E., \& Frazer, L. (2007). Dance Science Research Report. London: Hampshire Dance, Laban, Arts Council England. https:/ / doi.org/10.2307/1478284

Riddle, S. (2016). On music and literacy learning in the middle years. Literacy Learning: The Middle Years, 24(3), 16. https://search.informit.org/doi/10.3316/informit.360155145675345

Robertson, W., \& Lesser, L.M. (2013). Scientific skateboarding and mathematical music: Edutainment that actively engages middle school students. European Journal of Science and Mathematics Education, 1(2), 60-68. https://dx.doi.org/10.30935/scimath/9388

Rosli, R., Goldsby, D., \& Capraro, M. M. (2015). Using Manipulatives in Solving and Posing Mathematical Problems. Creative Education, 6(16), 1718. http:/ / dx.doi.org/10.4236/ce.2015.616173

Samson, S., \& Zatorre, R. (2004). Recognition memory for text and melody of songs after unilateral temporal lobe lesion: Evidence for dual coding. Psychology, Learning, Memory, Cognition, 1991(17), 193-804. https://doi.org/10.1037/02787393.17.4.793

Scott, A.W., (2005). Investigating traditional instruction and problem-based learning at the elementary level. Mississippi State University.

Shilling, W. A. (2002). Mathematics, music, and movement: Exploring concepts and connections. Early Childhood Education Journal, 29, 179-184. https://doi.org/10.1023/A:1014536625850

Wiggins, D. G. (2007) Pre-K music and the emergent reader: Promoting early literacy in a music enhanced environment. Early Childhood Education Journal, 35(1), 55-64. https:// doi.org/10.1007/s10643-007-0167-6

Yin, R. K. (2009). Case study research: Design and methods (4th Ed.). Thousand Oaks, CA: Sage. https://doi.org/10.33524/cjar.v14i1.73 